\title{
Optimization of selection process of constituent materials for high performance concrete and mortars
}

\author{
Nataliya Lushnikova \\ Department of Architecture \& Environmental Design, Educational and Research Institute \\ of Civil Engineering and Architecture, National University of Water Management and Nature \\ Resources Use, Rivne,Ukraine, e-mail: nataliya.lushnikova@gmail.com
}

\begin{abstract}
The paper gives coverage on approach to the optimization of selection process of constituents for high performance concrete (HPC) and mortars. There is shown the example selection of cement, mineral and chemical admixtures, as the most costly and influential on concrete, from the point of their maximum efficiency, measured by flowability and compressive strength increasing indexes. Method combines models for determination of activity indexes with simple stochastic equations obtained at mathematical treatment of experimental results.
\end{abstract}

Keywords: high performance concrete, mortar, chemical admixture, mineral admixture, superplasticizer, metakaolin, activity index.

\section{Introduction}

There exist different guidelines and methods of constituents' selection for concrete and mortars, both regulatory and advisory [1-4].

Any recommendations require preliminary laboratory batching that usually deals with selection process of constituents types and their rational proportioning. Modern production technologies of HPC and mortars include obligatory using reactive mineral and high range water reducing admixtures (HRWR) or composite admixtures based on them and require rational selection of binders as well as aggregates [5,6]. Application of such admixtures aims to reduce cement consumption and viscosity of fresh mixtures, increase strength, improve durability of hardened concrete and mortar [6,7]. Cost, energy and resources consumption of admixtures as well as cement are rather high, comparing to aggregates. Therefore, an important aspect of such cement-based systems is judicious choice of constituent materials aimed to obtain economical concrete and mortar [7].

In this connection, important aspect of simultaneous application of different admixtures in cement-based systems is their compatibility with each other and with cement. Testing thermokinetic parameters of cement hydration is an effective method for estimation of compatibility [8]. These parameters allow prediction a series of properties for cement and concrete [9]. Thus, such method along with its high accuracy requires special equipment.

There are known other parameters suggested for measuring effectiveness of mineral admixtures as well as their combinations with HRWR [10-14]. Thus the parameters, representing combined effect of cement and admixtures on flowability of fresh concrete and concrete strength, are the most adoptable to practical concrete manufacturing conditions $[14,15]$. Deterministic dependencies for calculation of these parameters can be incomplete as they do not take into account some uncertainties. Whereas stochastic equations consider probabilistic distribution of factors values. 
Therefore, it was suggested to use these simple deterministic equations and experimental models for estimation of efficiency of HPC and mortars constituent materials.

Comparatively widespread in Ukraine constituents were under consideration: local Portland cement, one of the most common superplasticizers S-3 of naphthalene formaldehyde type and metakaolin, obtained by dehydroxylation of kaolin clays, a highly reactive aluminosilicate mineral admixture. There are massive deposits of kaolin are located in Ukraine as well as several manufacturers of metakaolin [16].

The effect of metakaolin on high performance concrete and mortars is comparable to that of silica fume in terms of strength development rate, chloride ions permeability, drying shrinkage, frost resistance [4,17]. At the same time, metakaolin has some advantages comparing to silica fume. It does not darken concrete as silica fume does. Therefore, the architects prefer it. Due to lower specific surface than silica fume, metakaolin has lower water requirement and therefore reduced dosages of high range water reducing (HRWR) admixtures [4]. As Ukraine does not have any internal sources of silica fume, it makes metakaolin the only common local reactive mineral admixture.

Most of the researches prove that pozzolanic activity of metakaolin is slightly lower than that of silica fume [4], thus it corresponds to the activity of natural volcanogenic pozzolans and calcined natural pozzolans $[18,19]$.

\section{Aim and scope of the research}

The aim of current research was the solving the problem of rational selection of main concrete components (Portland cement, mineral and chemical admixtures as components of composite dry pack modifier) for further investigation of fresh and hardened concrete properties. On a whole, binders and admixtures as reactive components are considered the most influential on concrete and mortars properties. They are also the most expensive components. Therefore, the rational selection of their type and amount is one of the key aspects of concrete and mortar technology.

The results of the research can be spread on other cement-based systems containing mineral additions and chemical admixtures (like building mortars, grouts etc.), mostly they are vital for high performance cement-based systems.

\section{A method for determining the efficiency of cement and admixtures}

Due to high water consumption, most of reactive mineral admixtures are effective only at presence of high dosages of HRWR admixtures - superplasticizers, even if they substitute cements partially [4]. Therefore, a meaningful efficiency factor is strength increase, obtained by increasing the SP dosage and reduced cement content.

For determination of the efficiency of constituents there has been applied a method developed by prof. V.G. Batrakov at alias and stated in specification for composite concrete additions containing HRWR and mineral admixtures [20]. The method was selected due to simplicity of its implementation and unambiguity of the interpretation of received results.

There were prepared mortars of following proportion according to the requirements of specification:

1) control - without any admixtures at weight ratio $C($ ement $): S($ and $)=1: 3$;

2) basic - with composite modifier at weight ratio;

$\mathrm{C}($ ement $): \mathrm{A}($ ddition $): \mathrm{S}($ and $)=0.9: 0.1: 3$

where $\mathrm{C}$ - cement, $\mathrm{S}$ - sand, $\mathrm{A}$ - composite addition, consisted of superplasticizer and metakaolin. There was fixed proportion between superplasticizer and metakaolin as 0.1:0.9 in the research. 
Water-binder ratio of all basic mortars was equal to control one. Water binder ratio means ratio between water and cement (cement+admixtures) weight.

According to this method, activity indexes of composite admixture consisted of superplasticizer and metakaolin, are following:

1) coefficient of flowability increasing for basic mixtures is determined as follows:

$$
K_{f}=\frac{D_{b}-D_{c}}{D_{c}} \times 100,
$$

where $D_{b}$ - spread diameter of the basic mortar, $\mathrm{mm} ; D_{c}$ - spread diameter of the control mortar, mm.

2) coefficient of strength increasing of basic mortar is determined as follows:

$$
K_{s}=\frac{R_{s}^{b}-R_{s}^{c}}{R_{s}^{c}} \times 100,
$$

where $R_{s}^{b}$ - compressive strength of the basic mortar, MPa; $R_{s}^{c}$ - compressive strength of the control mortar, $\mathrm{MPa}$.

\section{Materials properties}

During research, following materials were used. As basic components there were used local Portland Cement CEM I 52.5 DIN 11641, EN-196 and quartz sand. As mineral component of composite admixture metakaolin was used. HRWR of naphthalene formaldehyde type S-3 was used as chemical component of composite admixture.

As it has been proven by researches [21, 22], the application of pozzolanic admixtures is more effective for pure Portland cement without mineral admixtures. The additions presented in cements of types II-V react themselves with clinker minerals, forming additional amount of hydrated compounds. Therefore, it may lead to reduction of the effect of reactive mineral additions like metakaolin.

Table 1. Chemical and mineralogical properties of the cements. $\%$ by weight

\begin{tabular}{ccccc}
\hline \multirow{2}{*}{ No. } & \multirow{2}{*}{ Property } & Formula & \multicolumn{2}{c}{ Value } \\
\cline { 3 - 5 } & & $\mathrm{CaO}$ & 67.15 & $\mathrm{PC}_{2}$ \\
\hline 1 & Calcium oxide & $\mathrm{SiO}_{2}$ & 21.70 & 65.58 \\
\hline 2 & Silicon oxide & $\mathrm{Al}_{2} \mathrm{O}_{3}$ & 5.36 & 22.05 \\
\hline 3 & Aluminum oxide & $\mathrm{Fe}_{2} \mathrm{O}_{3}$ & 4.10 & 4.73 \\
\hline 4 & Ferric oxide & $\mathrm{FeO}$ & - & 4.42 \\
\hline 5 & Ferrous oxide & $\mathrm{MgO}$ & 0.74 & 0.06 \\
\hline 6 & Magnesium oxide & $\mathrm{Cl}$ & - & 1.62 \\
\hline 7 & Cl - ion content & $\mathrm{IR}$ & 0.28 & 0.012 \\
\hline 8 & Insoluble residue & $\mathrm{LOI}$ & 0.34 & 0.1 \\
\hline 9 & Loss on ignition & $\mathrm{LSF}$ & 0.94 & 0.28 \\
\hline 10 & Lime saturation factor & $\mathrm{n}$ & 2.34 & 0.91 \\
\hline 11 & Silica modulus & $\mathrm{p}$ & 1.31 & 2.41 \\
\hline 12 & Aluminous modulus & $\mathrm{C}_{3} \mathrm{~S}$ & 65.17 & 1.07 \\
\hline 13 & Tricalcium silicate & $\mathrm{C}_{2} \mathrm{~S}$ & 13.06 & 60.01 \\
\hline 14 & Dicalcium silicate & $\mathrm{C}_{3} \mathrm{~A}$ & 7.26 & 18.30 \\
\hline 15 & Tricalcium aluminate & $\mathrm{C}_{4} \mathrm{AF}$ & 12.46 & 5.03 \\
\hline 16 & Tetra-calcium aluminoferrite & & & 13.43 \\
\hline & & &
\end{tabular}


Portland cement. Two kinds of local cement have been under research. Their chemical and mineralogical composition is given in Tab. 1, physical and mechanical properties - in Tab. 2. Portland cement lettered as $\mathrm{PC}_{1}$, according to its mineralogical composition is medium alumina cement, which is typical for Ukrainian cement industry. Another Portland cement, lettered as $\mathrm{PC}_{2}$, is low alumina cement.

Raised $\mathrm{C}_{3} \mathrm{~A}$ content may cause higher values of early age strength for $\mathrm{PC}_{1}$. In addition, $\mathrm{PC}_{1}$ has lower value of normal consistency due to its lower specific surface.

Table 2. Physical-mechanical properties of cement

\begin{tabular}{cccc}
\hline \multirow{2}{*}{ No. } & Property & \multicolumn{2}{c}{ Value } \\
\cline { 2 - 4 } & Fineness (008 sieve fraction content), $\%$ & $\mathrm{PC}_{1}$ & $\mathrm{PC}_{2}$ \\
\hline 2 & Specific surface by Blain, $\mathrm{m} 2 / \mathrm{kg}$ & 5 & 1 \\
\hline 3 & Normal consistency, $\%$ & 330 & 350 \\
\hline 4 & Setting time: initial & 24.0 & 27.5 \\
\hline 5 & final & $1 \mathrm{~h} 35 \mathrm{~min}$ & $3 \mathrm{~h}$ \\
\hline 6 & $3 \mathrm{~h} 45 \mathrm{~min}$ & $5 \mathrm{~h}$ \\
\hline & Uniformity of volume change & stands the test & stands the test \\
\hline 7 & Flexural strength, MPa: & 5.65 & 4.83 \\
& 2 days & 8.75 & 9.70 \\
\hline 8 & 28 days & 23.70 & 19.38 \\
& Compressive strength, MPa: & 54.00 & 53.80 \\
\hline
\end{tabular}

Quartz sand. For preparation of mortars there was used quartz sand. Properties of sand are given in Tab. 3 .

Table 3. Physical properties of quartz sand

\begin{tabular}{cccccc}
\hline $\begin{array}{c}\text { Density, } \\
\mathrm{g} / \mathrm{cm}^{3}\end{array}$ & $\begin{array}{c}\text { Bulk density, } \\
\mathrm{kg} / \mathrm{m}^{3}\end{array}$ & $\begin{array}{c}\text { Voidage, } \\
\%\end{array}$ & $\begin{array}{c}\text { Water demand, } \\
\%\end{array}$ & $\begin{array}{c}\text { Dust and clay } \\
\text { particles, less than } \%\end{array}$ & $\begin{array}{c}\text { Fineness } \\
\text { modulus }\end{array}$ \\
\hline 2.645 & 1485 & 43.8 & 7 & 2 & 2.03 \\
\hline
\end{tabular}

Superplasticizer. According to standard classification ASTM C494 superplasticizer S-3 of naphthalene-formaldehyde type belongs to chemical admixtures of type F waterreducing, high range admixture.

Content of "active substance" in HRWR is not less than $69 \%$, ash content - less than $38 \%, \mathrm{pH}$ of aqueous solution with concentration $2.5 \%-7 \ldots 9$. There was also used superplasticizer S-3, modified by defoarming agent PTV (polyethylene vinylene) in the amount $0.01 \%$ by superplasticizer weight. Defoarming agent is added for elimination of excessive air-entraining in concrete and mortars, which caused by mineral admixture as well as by high dosages of HRWR, characteristic of high-performance concrete. Such additional compaction of the mixture leads to increasing of strength and durability parameters of concrete. Therefore, such composite admixture solves complex problem of simultaneous high water reducing or reduction of water demand at minimal air-entraining.

Superplasticizer S-3 is lettered as $\mathrm{SP}_{1}$, another one modified with defoamer is lettered as $\mathrm{SP}_{2}$.

Metakaolin belongs to type N - calcined natural pozzolans according to ASTM C 618 classification. There were used three metakaolin samples made on local kaolin of AKW Ukrainian Kaolin Company (Glukhovetsky kaolin plant, Glukhivtsy, Vinnitsa region, Ukraine). Three samples of metakaolin lettered as $\mathrm{MTK}_{1}, \mathrm{MTK}_{2}, \mathrm{MTK}_{3}$, manufactured by 
Euroresource Corp. (Kiev, Ukraine) varied in chemical composition and physical properties (see Tab. 4-6). Engelhard Corporation (Iselin, New Jersey USA) manufactured metakaolin as a trademark Metamax EF; the sample is lettered as $\mathrm{MTK}_{4}$.

Samples of metakaolin \#1-3 were ground to obtain dispersity, equivalent to sieve \#0045 residues less than $0.3 \%$.

Method of laser granulometry was used for particle-size distribution of metakaolin. Results are given in Tab. 5 and in Fig. 1.

Table 4. Chemical composition of metakaolin samples

\begin{tabular}{cccccccccccc}
\hline \multirow{2}{*}{ Sample } & \multicolumn{10}{c}{ Oxides content, \% } \\
\cline { 2 - 13 } & $\mathrm{SiO}_{2}$ & $\mathrm{Al}_{2} \mathrm{O}_{3}$ & $\mathrm{Fe}_{2} \mathrm{O}_{3}$ & $\mathrm{TiO}_{2}$ & $\mathrm{CaO}$ & $\mathrm{MgO}$ & $\mathrm{MnO}$ & $\mathrm{Na}_{2} \mathrm{O}$ & $\mathrm{K}_{2} \mathrm{O}$ & $\mathrm{P}_{2} \mathrm{O}_{5}$ & LOI \\
\hline $\mathrm{MTK}_{1}$ & 52.5 & 42.20 & 0.34 & 0.70 & 0.30 & 0.25 & 0.01 & 0.10 & 0.90 & - & 0.50 \\
\hline $\mathrm{MTK}_{2}$ & 54.6 & 40.25 & 0.78 & 1.08 & 0.28 & 0.28 & 0.01 & 0.08 & 0.60 & 0.04 & 0.48 \\
\hline $\mathrm{MTK}_{3}$ & 52.5 & 42.20 & 0.34 & 0.70 & 0.30 & 0.25 & 0.01 & 0.10 & 0.90 & - & 0.50 \\
\hline $\mathrm{MTK}_{4}$ & 53.0 & 43.00 & $<1.20$ & $<1.5$ & 0.10 & $<0.1$ & - & $<0.05$ & $<0.4$ & - & $<1.0$ \\
\hline
\end{tabular}

Table 5. Particle-size distribution of metakaolin samples

\begin{tabular}{cccccccc}
\hline Sample & $<63 \mu \mathrm{m}$ & $<30 \mu \mathrm{m}$ & $<15 \mu \mathrm{m}$ & $<5 \mu \mathrm{m}$ & $<2 \mu \mathrm{m}$ & $\mathrm{d}_{50}, \mu \mathrm{m}$ & $\mathrm{d}_{90}, \mu \mathrm{m}$ \\
\hline $\mathrm{MTK}_{1}$ & 100 & 87.26 & 74.28 & 55.63 & 38.03 & 3.62 & 34.65 \\
\hline $\mathrm{MTK}_{2}$ & 100 & 98.49 & 88.20 & 61.60 & 43.10 & 2.83 & 16.30 \\
\hline $\mathrm{MTK}_{3}$ & 100 & 97.02 & 85.45 & 64.64 & 48.30 & 2.18 & 18.97 \\
\hline $\mathrm{MTK}_{4}$ & 100 & 100 & 99.36 & 92.20 & 73.00 & 1.04 & 4.30 \\
\hline
\end{tabular}

Note. $d_{50}$ and $d_{90}$-diameters of conventional cell, through which $50 \%$ and $90 \%$ (vol.) of metakaolin sample pass.

The data above show, that metakaolin under test has particle size up to $60 \mu \mathrm{M}$. Samples $\mathrm{MTK}_{1}-\mathrm{MTK}_{3}$ have substantial volume of particles of $1 \mu \mathrm{m}$ and $60 \mu \mathrm{m}$ with medium fraction deficiency $(5-10 \mu \mathrm{m})$.Sample $\mathrm{MTK}_{4}$ has higher uniformity of particle size: most of the particles have diameter from 0.5 to $50 \mu \mathrm{m}$.

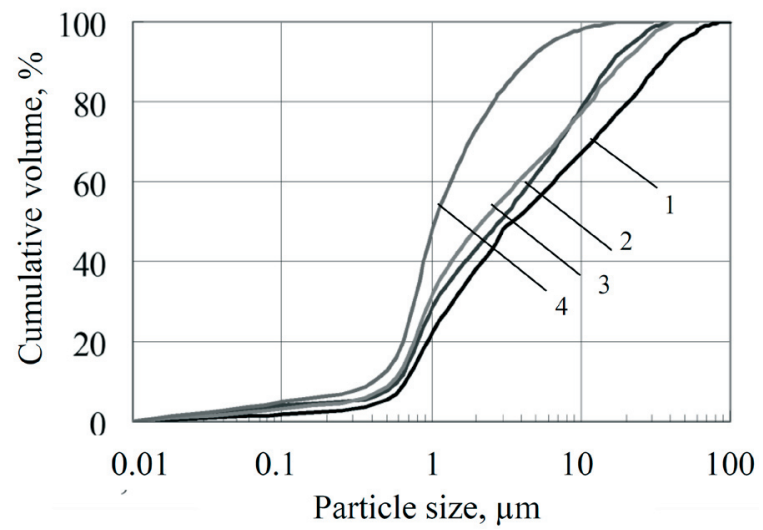

Fig. 1. Particle-size distribution of metakaolin: $1-\mathrm{MTK}_{1} ; 2-\mathrm{MTK}_{2} ; 3-\mathrm{MTK}_{3} ; 4-\mathrm{MTK}_{4}$

Specific surface was determined by calculating method on basis of the particle size distribution data. Pozzolanic activity of metakaolin was determined by $\mathrm{CaO}$ absorption. Physical and chemical properties of metakaolin samples are given in Tab. 6. 
Table 6. Physical and chemical properties of metakaolin

\begin{tabular}{cccccc}
\hline Sample & $\begin{array}{c}\text { Specific surfaces } \\
\text { (by mass), } \\
\mathrm{m}^{2} / \mathrm{kg}\end{array}$ & $\begin{array}{c}\text { Density, } \\
\mathrm{g} / \mathrm{cm}^{3}\end{array}$ & $\mathrm{~kg} / \mathrm{m}^{3}$ & $\%$ & $\begin{array}{c}\text { Bulk density, Normal consistency, } \\
\text { mg/g (by CaO } \\
\text { absorption) }\end{array}$ \\
\hline $\mathrm{MTK}_{1}$ & 1380 & 2.50 & 400 & 43 & 19 \\
\hline $\mathrm{MTK}_{2}$ & 1670 & 2.50 & 410 & 46 & 26 \\
\hline $\mathrm{MTK}_{3}$ & 1800 & 2.50 & 350 & 54 & 25 \\
\hline $\mathrm{MTK}_{4}$ & 2590 & 2.50 & 280 & 60 & 42 \\
\hline
\end{tabular}

As it is shown in Tab. 4 and 6, samples $\mathrm{MTK}_{1}$ and $\mathrm{MTK}_{3}$ have the same chemical composition but differ by specific surface. Chemical composition of sample $\mathrm{MTK}_{2}$ slightly differs from them, thus the total amount of reactive silica and alumina is almost equal (94.7\% against $94.85 \%$ for $\mathrm{MTK}_{1}$ and $\mathrm{MTK}_{3}$ ). Sample $\mathrm{MTK}_{4}$ has highest amount of $\mathrm{SiO}_{2}$ and $\mathrm{Al}_{2} \mathrm{O}_{3}(96 \%)$ and highest specific surface. Due to high specific surface, this sample demonstrates highest normal consistency and pozzolanic activity.

As data reveal, increasing of specific surface of metakaolin leads to its regular increasing of normal consistency and increasing of pozzolanic activity. That is mostly the reason for opening of new active surfaces of metakaolin grains as well as possible surface amorphization during deep grinding [23].

\section{Specimens preparation, storage and testing}

Mixes have been prepared according to standard requirements adapted to such mortars with admixtures [24]. Error of batching by weight was less than $1 \%$.

Electric mixer was used for mortars preparation. Cement, modifier (where required) and $1 / 3$ of sand were mixed during $1 \mathrm{~min}$. In dry mix water was added, and then mixed during $1 \mathrm{~min}$. Then $2 / 3$ of sand was added and mortar was mixed during $3 \mathrm{~min}$.

Water-binder ratio in control mortar should be sufficient for flow spread diameter equal $113-114 \mathrm{~mm}$.

At the $1^{\text {st }}$ stage of research have been conducted series of comparative experiments on determining the influence of superplasticizer on air-content of the mortars. $\mathrm{SP}_{1}$ and $\mathrm{SP}_{2}$, Portland cement $\mathrm{PC}_{1}$ and metakaolin $\mathrm{MTK}_{2}$ were used. Composite admixture content was $10 \%$ by binder weight. Superplasticizer content was fixed at the level 5,10 and $15 \%$ by composite admixture weight $(0.5,1.0$ and $1.5 \%$ correspondingly by binder weight).

There were prepared 3 batches for $\mathrm{SP}_{1}$ and $\mathrm{SP}_{2}$ with dosages of superplasticizer given above. Gravitational method was applied according to ASTM C 138. For each batch 2 samples were tested.

At the $2^{\text {nd }}$ stage of research there were conducted 3 sets of experiments:

$1^{\text {st }}$ set: Portland cement $\mathrm{PC}_{1}$, superplasticizer $\mathrm{SP}_{1}$;

$2^{\text {nd }}$ set: Portland cement $\mathrm{PC}_{2}$, superplasticizer $\mathrm{SP}_{1}$;

$3^{\text {rd }}$ set: Portland cement $\mathrm{PC}_{1}$, superplasticizer $\mathrm{SP}_{2}$.

Each set included 4 batches, with specific samples of metakaolin used in each one at other constant conditions. The mixing proportions were as it was described in part 3 .

For each batch spread flow was determined twice and prepared 3 mortar specimens.

For each batch, three $70.7 \mathrm{~mm}$ edge cubes were prepared. The specimens were kept in the molds during $24 \mathrm{~h}$ and after that hardened during 27 days in constant climate chamber with a relative humidity about $100 \%$ and temperature of $18 \pm 20{ }^{0} \mathrm{C}$. The strength characteristics were measured using a test machine FP 500/1 with a $500 \mathrm{kN}$ load capacity and accuracy $\delta= \pm 1.0 \%$. Compressive strength at the age of 28 days was tested according to standard requirements [25]. 


\section{Results and discussion}

\subsection{Air-entraining in mortars}

Rational air-content makes positive influence on durability of concrete and mortar. According to available data, air content $10-20 \%$ resulted in improved durability without causing serious reductions in compressive strength for cement-based mortars [26]. At the same time reduced air bubbles content seems to increase the workability and rheology of the mixtures [27]. For some types of concrete air entraining is mandatory. In any case attention should be paid to air entraining, since certain properties of supplementary cementing materials used in HPC greatly influence air-void system stability [28].

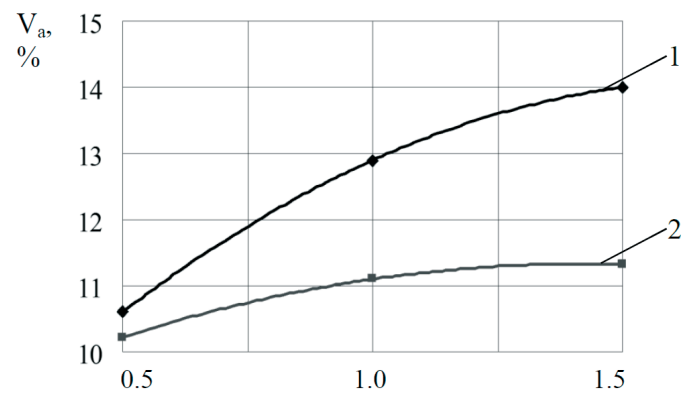

a)

Superplasticizer content, $\%$ by binder weight

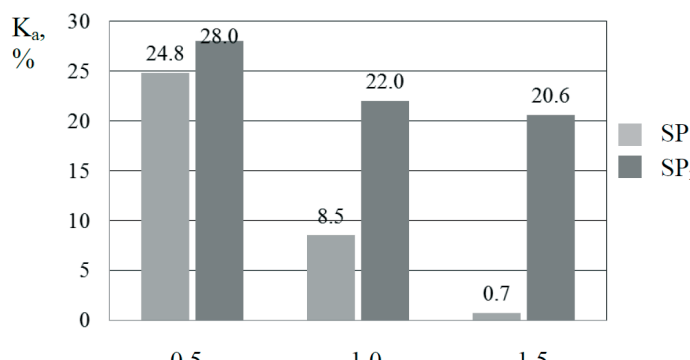

0.5

1.0

1.5

b) Superplasticizer content, $\%$ by binder weight

Fig. 2. Influence of superplasticizer type and content on: a) air content of mortars; b) index of air content change $1-\mathrm{SP}_{1} ; 2-\mathrm{SP}_{2}$

For control mortar air content was $V_{a}=14.1 \%$. Water binder ratio in all the batches was 0.41 .

Dependences of air content on SP content can be approximated by parabolic equations:

for $\mathrm{SP}_{1}: \quad V_{a}=-2.4 \cdot \mathrm{SP}_{1}^{2}+8.2 \cdot \mathrm{SP}_{1}+7.1$

for $\mathrm{SP}_{2}: \quad V_{a}=-1.3 \cdot \mathrm{SP}_{2}{ }^{2}+3.7 \cdot \mathrm{SP}_{2}+8.7$.

Index of air content change can be determined as follows:

$$
K_{a}=\frac{V_{a . c}-V_{a . b}}{V_{a . c}} \cdot 100
$$

where $V_{a . c}, V_{a . b}$ - air content, $\%$ of control and basic mortars correspondingly. 
Comparative dependences of air content of mortars and indexes of air content change are shown in Fig. 2.

As it can be seen, introduction of superplasticizer leads to reduction of air content comparing to control mortar due increasing of flowability of mortars at $25 \%$ and at $28 \%$ when defoamer is used. Thus increasing of superplasticizer content dramatically reduces its effect. At increasing $\mathrm{SP}_{1}$ dosage of from 0.5 to $1.5 \%$ the air content of the mortar is almost equal to that of control mortar regardless of high increasing of flowability. That confirms known data about intensive air-entraining of this HRWR at high dosages $[21,22]$. It is expected that application of defoaming agent allows obtaining slight decreasing of air content even when high dosages of $\mathrm{SP}_{2}$ are used and provide higher plastifying effect and higher strength of mortars and concrete.

\subsection{Activity indexes}

Basic mortars had following parameters:

- for $\mathrm{PC}_{1}$ applied $W / C=0.41$; spread diameter at flow table $F_{b}=114 \mathrm{~mm}$, compressive strength at the age of 28 days $R_{c}^{c}=47.0 \mathrm{MPa}$;

- for $\mathrm{PC}_{2}$ applied $W / C=0.42$; spread diameter at flow table $F_{b}=114 \mathrm{~mm}$, compressive strength at the age of 28 days $R_{c}^{c}=45.6 \mathrm{MPa}$.

Average activity coefficients values are given in Tab. 7.

As the $K_{f}$ and $K_{s}$ values indicate, high water demand of metakaolin sample $\mathrm{MTK}_{4}$ makes negative effect on flowability (Tab. 7). Two processes, contrary by its effect growth of pozzolanic activity and simultaneous normal consistency increasing due to higher specific surface - indemnify each other, therefore under current terms of experiment negative value of flowability coefficient is observed (Tab. 7, batches No. 4, 8 and 12). At the same time, its influence on mortar strength is equal to that of $\mathrm{MTK}_{3}$.

Table 7. Activity coefficients of composite admixture

\begin{tabular}{|c|c|c|c|c|c|c|c|c|c|c|}
\hline $\begin{array}{l}\text { No. of } \\
\text { set }\end{array}$ & $\begin{array}{l}\text { No. of } \\
\text { batch }\end{array}$ & $\begin{array}{c}\text { Type of } \\
\text { PC }\end{array}$ & $\begin{array}{l}\text { Type } \\
\text { of SP }\end{array}$ & $\begin{array}{l}\text { Type of } \\
\text { MTK }\end{array}$ & $\begin{array}{l}F_{c}, \\
\mathrm{~mm}\end{array}$ & $\begin{array}{l}F_{b}, \\
\mathrm{~mm}\end{array}$ & $\begin{array}{l}K_{f}, \\
\%\end{array}$ & $\begin{array}{l}R_{s}^{c}, \\
\mathrm{MPa}\end{array}$ & $\begin{array}{l}R_{s}^{b}, \\
\mathrm{MPa}\end{array}$ & $\begin{array}{c}K_{s}, \\
\%\end{array}$ \\
\hline \multirow{4}{*}{1} & 1 & \multirow{4}{*}{$\mathrm{PC}_{1}$} & \multirow{4}{*}{$\mathrm{SP}_{1}$} & $\mathrm{MTK}_{1}$ & \multirow{4}{*}{114} & 188 & 65 & \multirow{4}{*}{47.0} & 50.5 & 8 \\
\hline & 2 & & & $\mathrm{MTK}_{2}$ & & 171 & 50 & & 54.4 & 16 \\
\hline & 3 & & & $\mathrm{MTK}_{3}$ & & 156 & 37 & & 55.4 & 18 \\
\hline & 4 & & & $\mathrm{MTK}_{4}$ & & 105 & -8 & & 56.6 & 17 \\
\hline \multirow{4}{*}{2} & 5 & \multirow{4}{*}{$\mathrm{PC}_{2}$} & \multirow{4}{*}{$\mathrm{SP}_{1}$} & $\mathrm{MTK}_{1}$ & \multirow{4}{*}{114} & 183 & 61 & \multirow{4}{*}{45.6} & 48.8 & 7 \\
\hline & 6 & & & $\mathrm{MTK}_{2}$ & & 165 & 45 & & 51.8 & 14 \\
\hline & 7 & & & $\mathrm{MTK}_{3}$ & & 150 & 31 & & 52.4 & 15 \\
\hline & 8 & & & $\mathrm{MTK}_{4}$ & & 100 & -12 & & 54.4 & 19 \\
\hline \multirow{4}{*}{3} & 9 & \multirow{4}{*}{$\mathrm{PC}_{1}$} & \multirow{4}{*}{$\mathrm{SP}_{2}$} & $\mathrm{MTK}_{1}$ & \multirow{4}{*}{114} & 197 & 73 & \multirow{4}{*}{47.0} & 51.2 & 9 \\
\hline & 10 & & & $\mathrm{MTK}_{2}$ & & 185 & 62 & & 55.4 & 18 \\
\hline & 11 & & & $\mathrm{MTK}_{3}$ & & 172 & 51 & & 56.0 & 19 \\
\hline & 12 & & & $\mathrm{MTK}_{4}$ & & 117 & 3 & & 56.1 & 19 \\
\hline
\end{tabular}

Application of metakaolin $\mathrm{MTK}_{4}$ can be effective from the point of flowability increasing only when more effective HRWR is applied. Therefore, further selection procedure was eliminated by samples $\mathrm{MTK}_{1}-\mathrm{MTK}_{3}$.

Dependences of activity indexes of mortars on specific surface $s$ of metakaolin at $s \in[1380 ; 1800] \mathrm{m}^{2} / \mathrm{kg}$ for each set of experiments can be approximated by parabolic equations. Depending on Portland cement and superplasticizer used, the equations are following: 
- for experimental set \#1 $\left(\mathrm{PC}_{1}, \mathrm{SP}_{1}\right)$ :

$K_{f}=-119\left(s \cdot 10^{-3}\right)^{2}+313 s \cdot 10^{-3}-140$,

$K_{s}=-29\left(s \cdot 10^{-3}\right)^{2}+116 s \cdot 10^{-3}-97$;

- for experimental set \#2 $\left(\mathrm{PC}_{2}, \mathrm{SP}_{1}\right)$ :

$K_{f}=-126\left(s \cdot 10^{-3}\right)^{2}+329 s \cdot 10^{-3}-155$,

$K_{s}=-39\left(s \cdot 10^{-3}\right)^{2}+144 s \cdot 10^{-3}-117$;

- for experimental set \#3 $\left(\mathrm{PC}_{1}, \mathrm{SP}_{2}\right)$ :

$K_{f}=-108\left(s \cdot 10^{-3}\right)^{2}+290 s \cdot 10^{-3}-122$,
$K_{s}=-56\left(s \cdot 10^{-3}\right)^{2}+201 s \cdot 10^{-3}-162 ;$

where $s$ is specific surface of metakaolin, $\mathrm{m}^{2} / \mathrm{kg}$.

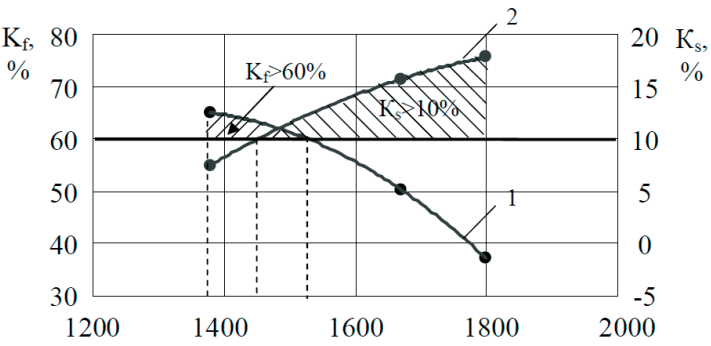

a)

$\mathrm{s}, \mathrm{m}^{2} / \mathrm{kg}$

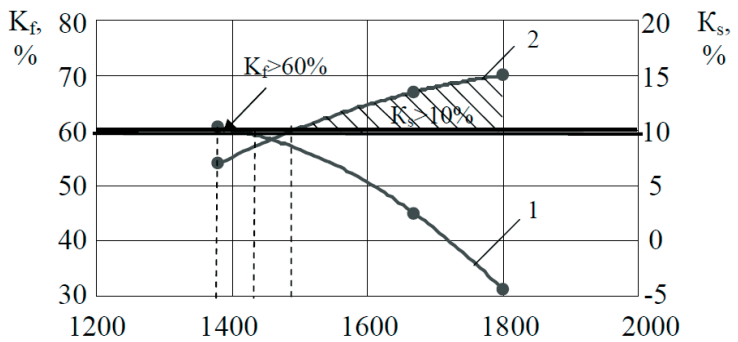

b)

$\mathrm{s}, \mathrm{m}^{2} / \mathrm{kg}$

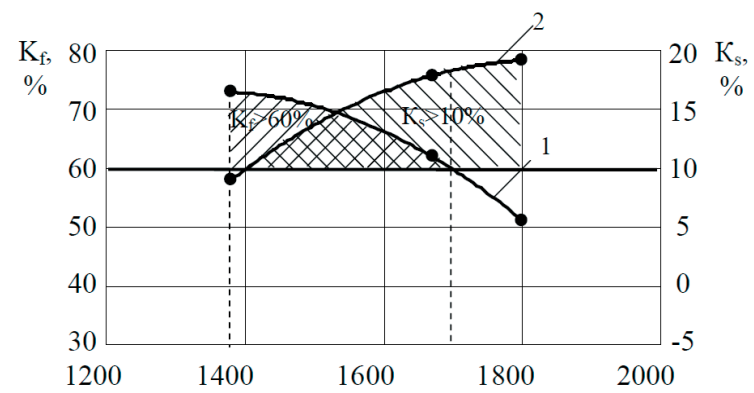

c)

$\mathrm{s}, \mathrm{m}^{2} / \mathrm{kg}$

Fig. 3. Influence of specific surface of metakaolin on activity parameters of composite admixture: a) $\mathrm{PC}_{1}, \mathrm{SP}_{1}$; b) $\mathrm{PC}_{2}, \mathrm{SP}_{1}$; c) $\mathrm{PC}_{1}, \mathrm{SP}_{2} ; 1$ - approximating curve of coefficient of flowability increasing, $K_{f}, \% ; 2$ - approximating curve of coefficient of strength increasing $K_{s}, \%$ 
Fig. 3 demonstrates graphical dependences of activity coefficients on specific surface of metakaolin (approximating curves 1 and 2). Comparing the values of activity coefficients for mortars specimens sets \#1 and 2 (Fig. 3a, 3b) it should be mentioned that flowability coefficient values are lower for $\mathrm{PC}_{2}$ based mortars, that is caused by higher water demand of this cement. Strength of the $\mathrm{PC}_{2}$ based specimens is also slightly lower. That effect can be explained by lower content of $\mathrm{C}_{3} \mathrm{~S}$ and $\mathrm{C}_{3} \mathrm{~A}$ minerals, which have higher hardening rate in early age. Comparing the results of the experimental sets \#1 and 2 it can be seen, that Portland cement $\mathrm{PC}_{1}$ is more effective than $\mathrm{PC}_{2}$ as it has lower normal consistency. As it can be seen from comparing results of sets \#1 and 3 , among two superplasticizers $\mathrm{SP}_{2}$ is more effective one.

Substitution of $\mathrm{SP}_{1}$ for $\mathrm{SP}_{2}$ leads to increasing of activity indexes of mortars under other constant conditions (Tab.7, Fig. 3a and c).

\section{Selection of constituent materials}

For selection of optimal constituents, there must be established specified values of activity indexes. They were set according to requirements of specifications on such composite admixtures containing HRWR and pozzolanic mineral admixture (silica fume and fly ash), that has similar specific surface range as metakaolin samples \#1-3, superplasticizer and mineral admixture weight ratio is $1: 9$ and is the same as in current research [20]. The values are as follows: $K_{f} \geq 60 \%, K_{s} \geq 10 \%$.

$K_{f}$ and $K_{s}$ values in eq. (6)-(11) were substituted and 3 sets of inequalities (6)-(7), (8)-(9) and (10)-(11) have been solved.

Graphic approach is applied to demonstrate solution regions of inequalities' sets and determinations values for providing required activity indexes (Fig. 3, shaded areas). Thereby:

- for $1^{\text {st }}$ set of experiments $\left(\mathrm{PC}_{1}, \mathrm{SP}_{1}\right)$ :

when $K_{f} \geq 60 \% s \in[1380 ; 1530] \mathrm{m}^{2} / \mathrm{kg}$; when $K_{s} \geq 10 \% s \in[1450 ; 1800] \mathrm{m}^{2} / \mathrm{kg}$;

- for $2^{\text {nd }}$ set of experiments $\left(\mathrm{PC}_{2}, \mathrm{SP}_{2}\right)$ :

when $K_{f} \geq 60 \% s \in[1380 ; 1400] \mathrm{m}^{2} / \mathrm{kg}$; when $K_{s} \geq 10 \% s \in[1460 ; 1800] \mathrm{m}^{2} / \mathrm{kg}$;

- for $3^{\text {rd }}$ set of experiments $\left(\mathrm{PC}_{2}, \mathrm{SP}_{1}\right)$ :

when $K_{f} \geq 60 \% s \in[1380 ; 1680] \mathrm{m}^{2} / \mathrm{kg}$; when $K_{s} \geq 10 \% s \in[1410 ; 1800] \mathrm{m}^{2} / \mathrm{kg}$.

As given results demonstrate, at the $1^{\text {st }}$ set of experiments $\left(\mathrm{PC}_{1}\right.$ and $\left.\mathrm{SP}_{1}\right)$ required activity indexes are achieved within range $s \in[1450 ; 1530] \mathrm{m}^{2} / \mathrm{kg}$, at mixing ratio of samples $\mathrm{MTK}_{1}$ and $\mathrm{MTK}_{2}$ 1:1 (Fig. 3a). When $\mathrm{PC}_{2}$ and $\mathrm{SP}_{1}$ are applied, simultaneous providing indexes values is impossible (Fig. $3 \mathrm{~b}$ ). There are observed lower activity indexes values. The obtained data meets the results of known researches, which prove that HRWR and mineral admixtures have higher activity at medium alumina cements with low normal consistency [21]. Therefore, Portland cement $\mathrm{PC}_{2}$ is not appropriate for further research.

As it is shown in Fig. $3 \mathrm{c}$, when $\mathrm{PC}_{1}$ and $\mathrm{SP}_{2}$ are applied, required values of activity indexes is possible with the range $s \in[1410 ; 1680] \mathrm{m}^{2} / \mathrm{kg}$. Superplasticizer $\mathrm{SP}_{2}$ has higher water reducing and strength increasing effects due to additional mortar compaction. Among metakaolin samples MTK $_{2}$ meets the requirements on specific surface $\left(s=1670 \mathrm{~m}^{2} / \mathrm{kg}\right)$.

Regarding the results of tests and calculations, there were selected following constituent materials: Portland cement $\mathrm{PC}_{1}$, superplastisizer $\mathrm{SP}_{2}$ and metakaolin $\mathrm{MTK}_{2}$, as they enable to obtain required activity of composite admixture.

\section{Conclusions}

It has been determined activity indexes of composite admixture, which consists of superplasticizer and metakaolin, estimated by increasing the parameters of flowability and 
strength of mortar. Different factors like type and dosage of constituent materials, specific surface of mineral admixture and properties of cement affect significantly the activity of composite admixture.

By combined solving of simple deterministic and stochastic equations there have been obtained possible solution regions for different combinations of mortar constituents. As a result, cement, chemical and mineral components of composite admixture were selected to meet specified requirements as follows: medium alumina cement, superplasticizer with defoaming agent and metakaolin with specific surface $1670 \mathrm{~m}^{2} / \mathrm{kg}$.

The sequence of selection procedure is following:

1) ascertainment of quality parameters required (e.g. increasing of flowability and compressive strength) and their limit values;

2) determination of factors of constituent materials (e.g. specific surface of mineral admixture, dosage etc.) and realization of experiment;

3) calculation of quality parameters and obtaining of experimental equations, describing effects of factors on them;

4) determination of optimal values of variables which meet required quality parameters (by solving the set of inequalities for $K_{f}$ and $K_{s}$ ).

The approach can be applied for different types of concrete and mortars, but mostly for high energy and resources consuming high-performance concrete and mortars.

The method, presented in the paper, considers the only two parameters: flowability and compressive strength as the most essential ones. However, similar procedure can be applied for testing frost resistance and other properties attributable to durability of concrete and mortars. As at that rate the task of optimization is multiparametric, it might be supposed, that result will be different. Eligibility of the results obtained for cement-sand mortar should be verified for High Performance Concrete.

\section{References}

1 EN 206-1:2000, Concrete - Part 1: Specification, performance, production and conformity.

2 BS EN 934-2:2009+A1:2012, Admixtures for concrete, mortar and grout. Concrete admixtures. Definitions, requirements, conformity, marking and labeling.

3 ASTM C 618, Standard Specification for Fly Ash and Raw or Calcined Natural Pozzolan for Use as a Mineral Admixture in Portland Cement Concrete.

4 Caldarone M.A. High-Strength Concrete: A Practical Guide. CRC Press, 2008, 272p.

5 Fic S., Góra J., Piasta W. The influence of coarse carbonate aggregate on elastic deformation $(E C)$ and strength of HPC. Вісник Одеської державної академії будівництва та архітектури, Одеса 27 (2007) 318-322.

6 Nawy E.G. Fundamentals of High Strength High Performance Concrete. Longman Group Limited, Harlow, Longman Pub Group, 1996, 360p.

7 Bharatkumar B.H., Narayanan R., Raghuprasad B.K., Ramachandramurthy D.S. Mix proportioning of high performance concrete. Cement and Concrete Composites 23(1) (2001)71-80.

8 Usherov-Marshak A.V., Zlatkovskii O.A., Ciak M. Assessing the efficiency of chemical and mineral admixtures in early cement hydration. Inorganic Materials 40(8) (2004) 886-890. Translated from Neorganicheskie Materialy 40(8) (2004) 1014-1019.

9 Ciak M.J. Metoda oceny efektywności domieszek i kompatybilności systemu cement - domieszka. Badania Naukowe, Olsztyn: UWM 2 (2005) 122-123.

10 Батраков В.Г., Каприелов С.С., Иванов Ф.М., Шейнфельд А.В. Оиенка ультрадисперсных отходов металлургических производств как добавок в бетон. Бетон и железобетон. 12 (1990) 15-17.

11 Shvarzman A., Kovler K., Shamban I., Grader G.S., Shter G.E. Influence of chemical and phase composition of mineral admixtures on their pozzolanic activity. Advances in Cement Research 14(1) (2002) 35-41. 
12 Badogiannis E., Papadakis V.G., Chaniotakis E., Tsivilis S. Exploitation of poor Greek kaolins: strength development of metakaolin concrete and evaluation by means of $k$-value. Cement and Concrete Research 34(6) (2004) 1035-1041.

13 Dvorkin L., Dvorkin O. and Ribakov Y. Multi-Parametric Concrete Compositions Design. Nova Science Pub Inc., 2013, 223p.

14 Cyr M., Lawrence P., Ringot E. Efficiency of Mineral Admixtures in Mortars: Quantification of the Physical and Chemical Effects of Fine Admixtures in Relation with Compressive Strength. Cement and Concrete Research, 36(2) (2006) 264-277.

15 Dvorkin L., Bezusyak A., Lushnikova N., Ribakov Y. Using mathematical modeling for design of self-compacting high strength concrete with metakaolin admixture. Construction and Building Materials 37 (2012) 851-864.

16 Каолины Украиныл. Справочник. ред. Ф.В. Овчаренко, Киев, Наук. думка, 1982, 368 с.

17 Дворкін Л.Й., Лушнікова Н.В, Рунова Р.Ф., Троян В.В. Метакаолін в будівельних розчинах $i$ бетонах. К.: Вид. КНУБіА, 2007, 216p.

18 Wala D., Rosiek G. Mineraty ilaste jako dodatek pucolanowy do cementów hydraulicznych. CWB 1 (2003) 27-33.

19 Малолепши Я., Питель 3. Влияние метакаолина на свойства цементных растворов. Минеральные и химические добавки в бетон, под ред. А.В. Ушерова-Маршака, Харьков, Колорит, 2005, 61-77.

20 ТУ 5743-083-46854090-98, Модификатор бетона МБ-С. Технические условия. Москва, 1998.

21 Батраков В.Г. Модифицированные бетоны. Теория и практика. Москва, Технопроект, $1998,768 \mathrm{p}$.

22 Collepardi M. Il nuovo calcestruzzo, Tintoretto, 2003, 391 p.

23 Vizcayno C., Gutiérrez R.M., Castello R., Rodriguez E., Guerrero C.E. Pozzolan Obtained by Mechanochemical and Thermal Treatments of Kaolin. Applied Clay Science. 49 (2010) 405-413.

24 ASTM C230, Flow Table for Use in Tests of Hydraulic Cement.

25 ASTM C109 / C109M - 13, Standard Test Method for Compressive Strength of Hydraulic Cement Mortars (Using 2-in. or [50-mm] Cube Specimens).

26 Davison J.J. Effect of air-content on durability of cement-lime mortars. Durability of Building Materials 1 (1982) 23-34.

27 Dilsa J., Boelb V., De Schuttera G. Influence of cement type and mixing pressure on air content, rheology and mechanical properties of UHPC. Construction and Building Materials 41 (2013) 455-463.

28 Kerkhoff B., Benefits of Air Entrainment in HPC, HPC Bridge Views 23 (2002) 3.

\section{Optymalizacja procesu wyboru materiałów składowych do betonu i zapraw wysokowartościowych}

\section{Nataliya Lushnikova}

Katedra Architektury i Projektowania Środowiska, Wydziat Budownictwa i Architektury, Narodowy Uniwersytet Gospodarki Wodnej, Równe, Ukraina, e-mail:nataliya.lushnikova@gmail.com

Streszczenie: W artykule przedstawiono sprawozdanie na temat podejścia do optymalizacji procesu selekcji składników do betonu wysokowartościowego (BWW) oraz zapraw. Pokazany jest wybrany przykład stosunku cementu, minerałów i chemicznych domieszki, jako najbardziej kosztownych i wpływowych na beton, od punktu maksymalnej aktywności, mierzonej przez wzrostem indeksów zdolności do płynięcia i do wytrzymałości na ściskanie. Metoda łączy w sobie modele do oznaczania aktywności indeksów z prostymi równaniami stochastycznymi uzyskanymi przy obliczeniu wyników eksperymentalnych.

Słowa kluczowe: beton wysokowartościowy, zaprawa, domieszki chemiczne, domieszki mineralne, superplastyfikator, metakaolin, wskaźnik aktywności. 